\title{
PROCESY FORMOWANIA NARODÓW I TOŻSAMOŚCI NARODOWEJ W AMERYCE ŁACIŃSKIEJ
}

\author{
NATION AND NATIONAL IDENTITY FORMATION \\ IN LATIN AMERICA. SELECTED ISSUES
}

\begin{abstract}
The history of nation formation in Latin America cannot be easily interpreted within the frames of existing theoretical perspectives, such as modernism. The difficulty lies in the fact that the existing theories only partly apply to this region. The aim of this article is to present the processes of nation and national identity formation in Spanish America until the 1950s pointing to its main characteristics and selected factors of the most significant impact.
\end{abstract}

Key words: Latin America; nation; nationalism; national identity; national culture

\section{Streszczenie}

Historia powstawania narodów w Ameryce Łacińskiej nie daje się jednoznacznie zinterpretować $w$ ramach istniejących schematów i ujęć teoretycznych (np. modernizmu). Trudność polega na tym, że znajdują one jedynie częściowe zastosowanie w odniesieniu do Ameryki Łacińskiej. Celem artykułu jest przestawienie procesów tworzenia narodów i tożsamości narodowej w Ameryce hiszpańskiej do połowy XX wieku z uwzględnieniem wybranych głównych cech tego procesu i czynników, które miały na niego wpływ.

Słowa kluczowe: Ameryka Łacińska; naród; nacjonalizm; tożsamość narodowa; kultura narodowa

ANNA KAGANIEC-KAMIEŃSKA Uniwersytet Jagielloński, Kraków E-mail: a.kaganiec-kamienska@uj.edu.pl This work was supported by the author's own resources. No competing interests have been declared.

This is an Open Access article distributed under the terms of the Creative Commons Attribution 3.0 PL License (creativecommons.org/licenses/by/3.0/pl/), which permits redistribution, commercial and non-commercial, provided that the article is properly cited. (C) The Author(s) 2016.

Publisher: Institute of Slavic Studies, Polish Academy of Sciences [Wydawca: Instytut Slawistyki PAN] 


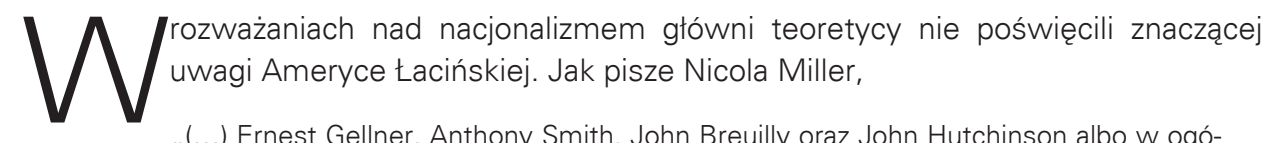
le ignorowali Amerykę Łacińską, albo wspominali o niej w niewygodnym przypisie, przyznając, że w rzeczywistości nie "pasuje» do żadnego z ich schematów, nie modyfikowali jednak ich ram, aby w jakiś znaczący sposób uwzględnić doświadczenia regionu (Miller, 2006, s. 203).

Jednym z wyjątków był Eric Hobsbawm, który napisał krótki, ale wartościowy esej "Nationalism and national identity in Latin America" (1995). Ważną i wpływową pracą jest książka Benedicta Andersona Wspólnoty wyobrażone (Imagined Communities, 1983, 1991, 2006), w której podjął on temat nacjonalizmu i ruchów narodowych w Amerykach oraz roli języka i druku w tym procesie. Rozważania Andersona spotkały się zarówno z pochwałami, jak i z krytycznymi uwagami (Holt, 2003; Miller, 2006), nie oznacza to jednak, że na wartości utraciły jego spostrzeżenia na temat istotnej roli prasy i innych publikacji, czyli „drukowanego kapitalizmu” (print-capitalism) w procesie formowania narodu. Jego refleksja nadal pozostaje punktem wyjścia wielu prac dotyczących regionu, nawet jeśli ostatecznie przyjmują one inną optykę (Holt, 2003; Miller, 2006).

Historia powstawania narodów w Ameryce Łacińskiej nie daje się zatem jednoznacznie zinterpretować w ramach istniejących schematów i ujęć teoretycznych (np. modernizmu). Jak ujmuje to Miller, „[p]rawdziwa trudność, jaką sprawia Ameryka Łacińska, leży nie w tym, że całkowicie nie przystaje ona do stosowanej normy, ale to, że wszystko dotyczy jej czéściowo. Zwyczajowo uznawane identyfikatory nacjonalizmu są obecne, lecz w skomplikowany sposób" (Miller, 2006, s. 203). Tak między innymi wygląda kwestia języka. Chociaż nie jest on kluczowym elementem formowania narodów w regionie, to nie można powiedzieć, że nie odegrał on żadnej roli w tym procesie (Miller, 2006).

Celem artykułu jest przestawienie procesu tworzenia narodów i tożsamości narodowej w Ameryce hiszpańskiej do połowy XX wieku z uwzględnieniem głównych jego cech oraz wybranych czynników, które miały na niego wpływ, takich jak rola państwa i elit oraz charakter społeczności stanowiącej podstawę tworzącego się narodu.

\section{SPÓR O POCZACTKI}

Ważnym głosem krytycznym wobec Andersona był Claudio Lomnitz (2001). Zakwestionował on jego definicję narodu w odniesieniu do regionu, wskazując, że „nie zawsze pokrywa się [ona] z historycznym użyciem tego terminu" (ss. 333-334). Wskazał również na jego błędy w interpretacji procesów niepodległościowych w regionie.

\section{Nacjonalizm pojawia się w okresie walk o niepodległość}

Zdaniem Andersona nacjonalizm narodził się wcześniej w społeczeństwach kreolskich w Amerykach niż w samej Europie (Anderson, 1997). Stwierdzenie to jest dla Lomnitza (2001) zaskakujące. Twierdzi on bowiem, że „przypadki Hiszpanii i Ameryki hiszpańskiej sugerują, że nacjonalizm rozwijał się stopniowo począwszy od europejskiej kolonizacji 
w XVI w. lub być może jeszcze od rekonkwisty" (s. 339). Według Lomnitza, reformy Burbonów były przejawem „świadomości patriotycznej i narodowej, która rozwinęła się od czasów podboju, świadomości która stworzyła jednocześnie jasno określony obraz «Hiszpanii» jako ziemi i "Hiszpanów» jako narodu (...)" (s. 345). Na przykładzie wzmianek pochodzących z "La Gazeta de Mexico" z 1784 roku poświęconych uroczystości z okazji narodzin następców tronu oraz podpisania przez Hiszpanię traktatu pokojowego z Francją i USA, Lomnitz pokazał, jak „oficjalny biuletyn” publikowany w Meksyku służył interesom Hiszpanii, ale równocześnie wydawał się włączać do pojęcia nación również miejscową społeczność kolonii, a przynajmniej Kreolów - mimo że w samej paradzie umieszczono alegorie odnoszące się do patria madre (Hiszpanii). Jak twierdzi Lomnitz, reformy administracyjne przeprowadzone przez Karola III Burbona (1759-1788) wyraźnie włączyły terytorialnie Indie Zachodnie do "Hiszpanii”. Reformy te doprowadzity z jednej strony do powstania idei Grán España (Wielkiej Hiszpanii obejmującej Iberię i Indie Zachodnie), z drugiej zaś do stworzenia różnych jednostek administracyjnych o własnej armii i finansach. Decentralizacja administracji miała między innymi ułatwić stawienie czoła niebezpieczeństwom ze strony Wielkiej Brytanii i rewolucji amerykańskiej. W ten sposób dzięki stworzeniu nowego systemu administracyjnego wzmocniono region politycznie, powstato również poczucie panimperialnej tożsamości (Lomnitz, 2001).

Z kolei sama niepodległość, zdaniem Lomnitza, nie była efektem nacjonalizmu kulturowego. Była raczej rezultatem osłabienia zdolności Hiszpanii do kierowania swoimi zamorskimi koloniami. „W efekcie, wiele z treści ideologii nowoczesnego nacjonalizmu (...) stanowiło kulturowy produkt niepodległości, a nie jej konieczny warunek" (s. 352, podkr. dodane).

\section{Kościót i rasa}

Anderson powiązał nacjonalizm w Ameryce Łacińskiej z procesem sekularyzacji, co Lomnitz postrzega za jego "fundamentalny błąd”. Jak twierdzi: „W Hiszpanii, gdzie naród uformował się zdecydowanie jako jeden z najwcześniejszych, ma miejsce coś odwrotnego: świadomość narodowa wyłania się jako odgałęzienie ekspansjonizmu religijnego" (Lomnitz, 2001, s. 339, pokreślenie dodane). De facto, „można nawet twierdzić, przeciwnie do Andersona, że sukces Ferdynanda, Izabeli i Karola $V$ dał nowe życie i wiarygodność narracji o Edenie" (s. 340).

Lomnitz zwraca też uwagę, że „organizacja społeczna państwa budowana w czasie ekspansji innowacyjnie utożsamiła Kościół z ideą narodową” (s. 341). Kościół został „znacjonalizowany", zaś wraz z ekspansją w Ameryce proces ten przybrat jeszcze bardziej na znaczeniu. Nacjonalizacja Kościoła leżała, jego zdaniem, w centrum historii hiszpańskiego (i hiszpańsko-amerykańskiego) nacjonalizmu, co, jak sam zaznacza, jest odwrotnym punktem wyjścia w stosunku do tego, który zaproponował Anderson, a mianowicie procesu sekularyzacji (ss. 342-343). Posiadacze certyfikatów o czystości krwi (stanowiących gwarancję, że byli Starymi Chrześcijanami) mogli zajmować wyższe stanowiska czy być członkami gildi. Byli postrzegani „jako społeczność krwi i wierzeń, która miała uprzywilejowany dostęp do państwa" (s. 341).

Według Lomnitza hiszpańskość (Spanishness) zrodziła się zatem z ich uprzywilejowanego powiązania z Kościołem. Hiszpanie byli ludem wybranym, prawdziwymi strażnikami wiary i „jedyną, zatem, żywotną polityczną, moralną i ekonomiczną elitą", którym przewodzili "Królowie Katoliccy" (s. 343). Miało im to dawać prawo do "sprawowania duchowej 
opieki nad Amerykami i całym światem” (s. 343). "Rasa” miała zatem kluczowe znaczenie dla wczesnego nacjonalizmu, w tym sensie, że pochodzenie od Starych Chrześcijan uważano za „znak historycznych powiązań z wiarą, znak, który daje ich posiadaczom kontrolę nad biurokratyczną aparaturą zarówno Kościoła, jak i państwa" (s. 352).

Lomnitz kwestionuje zatem twierdzenie Andersona o „ważniejszej roli języka niż rasy" w formowaniu narodów, zwracając uwagę, że rasa i język były ze sobą powiązane (s. 352). Również Thomas C. Holt zgadza się, że Anderson źle odczytał relacje między rasą i narodem (Holt, 2003), wskazując dodatkowo, że pominął on także ważną kwestię płci (co ukazał Gilberto Freyre, pokazując, że narodowy charakter Brazylijczyka wyłonił się „z seksualnego i kulturowego zjednoczenia pana i niewolnicy” (Holt, 2003, s. xiii)".

Ideologie narodowe i tożsamość w Ameryce Łacińskiej są w gruncie rzeczy nierozerwalnie związane z kwestią rasy. Była ona kluczowa zarówno w procesie podboju oraz kolonizacji regionu, jak i w okresie budowania narodów.

\section{Centralna rola języka drukowanego}

W swoich rozważaniach Anderson twierdzi, że to „drukowany kapitalizm” przyczynił się do uformowania się wspólnot czytelników, czyli owych narodowych „wspólnot wyobrażonych".

Analizując charakterystyczne cechy pierwszych gazet w Amerykach, które pojawity się dopiero w II połowie XVIII w., Anderson zauważył, że:

Oprócz wiadomości z metropolii podawały przede wszystkim informacje gospodarcze (dotyczące cen towarów w portach, terminów odpływania i przybijania statków) oraz o miejscowym nominacjach, małżeństwach ludzi zamożnych itd. innymi słowy, tym, co połączyło na jednej stronie gazety dane małżeństwo z określonym okrętem, taką to cenę z tym biskupem, była struktura kolonialnej administracji i system rynkowy. W ten to sposób gazeta, dajmy na to z Caracas, w sposób całkiem naturalny, a nawet apolityczny, rodziła poczucie przynależności do wyobrażonej wspólnoty czytelników, jakoś powiązanych z wymienionymi okrętami, małżeństwami, biskupami, czy cenami. Z biegiem czasu musiały bez wątpienia pojawiać się w nich akcenty polityczne (Anderson, 1997, s. 71, podkr. w tekście).

Zdaniem Andersona lokalne gazety odegrały znaczącą rolę w powstaniu poczucia pewnej wspólnoty czytelników w regionie Ameryki hiszpańskiej. Jak wyjaśnia: „Meksykański Kreol z paromiesięcznym opóźnieniem dowiedzieć się mógł o wydarzeniach w Buenos Aires, ale dowiadywał się o nich z gazet meksykańskich, a nie z ukazujących się w Rio de la Plata; wydarzenia te zaś nie wydawały mu się czéścią wydarzeń meksykańskich, były raczej podobne do nich" (Anderson, 1997, s. 72, podkr. w tekście).

Zatem znaczenie miało tutaj nie tyle to, $w$ jakim jezzyku publikowane były gazety (i książki), jak miało to miejsce w Europie, ile to, o czym te gazety pisały oraz na jakim terenie się ukazywały. Treść informacji, ich lokalność oraz zasięg gazet stanowiły czynnik dający podstawę utożsamienia się z daną wyobrażoną grupą czytelników.

Andersonowi z pewnością udało się pokazać znaczenie gazet, czasopism i wytworów literackich jako czynnika wspomagającego proces rozwoju świadomości narodowej. Jednak, jak zaznacza Miller, „nie udało mu się przekonać czytelnika, że drukowany kapitalizm był czynnikiem sprawczym uformowania się idei narodowej" (Miller, 1999, s. 39, podkreślenie dodane).

1 Szerzej na temat rasy i płci w Ameryce Łacińskiej, zob. np. Wade (1997, 2009). 
Jak stwierdził Aimer Granados García (2009), formowanie się tożsamości w Ameryce Łacińskiej było procesem kształtującym się najpierw w opozycji do Europy, a następnie w II połowie XIX wieku w opozycji do Stanów Zjednoczonych jako agresora (interwencje, ekspansjonizm)². Budzenie się świadomości rodziło pytania o charakter nowej tożsamości. Wielu ojców założycieli wyobrażało sobie powstanie zjednoczonego kontynentu i przedkładało tożsamość latynoamerykańską nad regionalną czy narodową (Francisco de Miranda, Simón Bolívar). Idea jedności kontynentu przemawiała także do innych intelektualistów i polityków, takich jak Eugenio María de Hostos (Portoryko), Francisco Bilbao (Chile), czy José María Samper (Kolumbia) (Granados García, 2009; Larrain, 2000).

Niemniej jednak jeszcze w epoce kolonialnej w regionie wyłoniły się różne tożsamości. Przykładowo, jak podaje argentyński historyk José Carlos Chiaramonte (1997a), już w XVII wieku w Meksyku powstała silna świadomość „meksykańskości” (niekoniecznie niekompatybilna z przynależnością do narodu hiszpańskiego), a w kolonialnym Chile wykształciło się poczucie przynależności do ziemi urodzenia. Chiaramonte (1989) w swoim szeroko cytowanym artykule zaznaczył, że w regionie Río de la Plata po 1810 roku wspótwystępowały de facto różne typy tożsamości zbiorowej: hispanoamericana - „kontynuacja poczucia "amerykańskości» (el español americano) wykształconego w okresie kolonialnym" (s. 71); provincial - prowincjalna, lokalna, osadzona w odczuciach mieszkańców pewnego obszaru; oraz rioplatense - czyli późniejsza argentyńska tożsamość narodowa. Istnienie silnych tożsamości w poszczególnych prowincjach jest wymieniane przez Jorge Myersa (2006) jako jeden z czynników, który utrudniał uformowanie się argentyńskiej tożsamości narodowej ${ }^{3}$.

Chiaramonte (1997b) zwrócił też uwagę, że około 1810 roku elity iberoamerykańskie używały pojęć „naród” (nación) oraz „państwo” (estado) jako synonimy, czego wyraz znaleźć można w licznych tekstach z epoki, także w dokumentach. Na różne użycie terminu nación w Meksyku w XVIII wieku zwrócił też uwagę Lomnitz (2001) w swojej krytyce Andersona. Termin nación mógł być definiowany zarówno w oparciu o terytorium, przeciwstawiając tym samym Hiszpanów (penisulares) Amerykanom, jak również kryterium więzi krwi i pochodzenia. Warto zatem pamiętać o wspótistnieniu w okresie kolonialnym tych dwóch dyskursów - lojalności względem ziemi oraz przynależności wynikającej z pochodzenia. Mniej więcej od 1830 roku w dyskursie ideologicznym i debacie na temat kultury poszczególnych krajów zaczął pojawiać się termin „narodowość” (nacionalidad) (Chiaramonte, 1997b).

\section{PERIODYZACJA}

W literaturze przedmiotu zaproponowano różne periodyzacje nacjonalizmu i procesów powstawania narodów w Ameryce Łacińskiej biorące pod uwage rozmaite czynniki polityczne, ekonomiczne i kulturowe (np. Whitaker, 1962; Hobsbawm, 1995; Wiarda, 2001).

2 Na temat dyskursów ideologicznych antyhispanizmu, hispanoamericanismo, hispanismo, anti-americanismo, pan-hispanismo zob. np. Wojcieszak (1989); Wiarda (2001); Granados García (2009).

3 Na temat rozwoju państwa argentyńskiego oraz myśli społeczno-politycznej zob. też klasyczne studium Halperín Donghi (1980). 
Jak się jednak wydaje, kluczową zmianą, jaka nastąpiła w pierwszych dekadach XX wieku było włączenie w ramy "narodu” wyłączonych wcześniej grup. Było to możliwe m.in. dzięki rewizji dotychczasowego sposobu postrzegania ras wywodzącego się z dominujących w tym czasie idei pozytywizmu czy darwinizmu społecznego (Larrain, 2000; Wiarda, 2001). Wyrazem odejścia od uprzywilejowywania rasy białej w imię uznania metysażu oraz Indianina była, na przykład, koncepcja „demokracji rasowej”. Jej prekursorem był José Vasconcelos z Meksyku (Rasa kosmiczna, 1925) (Wojcieszak, 1989, ss. 111-124), a autorami swego rodzaju manifestów Brazylijczyk Gilberto Freyre i Kubańczyk Fernando Ortiz w latach 30. i 40. XX wieku.

Hobsbawm (1995), modernista, wyróżnił trzy fazy nacjonalizmu w Ameryce Łacińskiej. Pierwsza trwała od uzyskania niepodległości do połowy XIX wieku. W tym czasie "naród" postrzegany był w rozumieniu oświeceniowym jako "lud", unia ludzi współmieszkających na danym terytorium, podległych wspólnemu systemowi prawnemu i politycznemu. Druga faza „zbiegła się W czasie z ustanowieniem władzy centralnej pod rządami liberałów w połowie XIX wieku, kiedy «naród» zaczęto utożsamiać z postępem definiowanym w kategoriach modernizacji dokonującej się poprzez rozwój gospodarczy (...)" (Miller, 1999, s. 35). Oznaczało to zatem większą ekskluzywność - członkami „narodu” mogli być jedynie ci, którzy byli zwolennikami postępu. Trzecia faza, trwająca od rewolucji meksykańskiej (1910-1917), to okres włączania mas w ramy narodu (popular nationalism). Jak stwierdza Hobsbawm, nacjonalizm tego typu dominował w regionie od lat 30. XX wieku. Chociaż ważną rolę dla zidentyfikowania się ludu z narodem odegrali populistyczni przywódcy, to jednak jego zdaniem, najważniejszym czynnikiem w tym procesie był "rozwój nowoczesnej kultury masowej, szczególnie wzmocnionej przez technologię" (Miller, 1999, s. 35).

Z kolei Howard J. Wiarda (2001) wskazuje na co najmniej trzy fazy nacjonalizmu latynoamerykańskiego). W fazie powolnego "nacjonalizmu liberalnego" (termin Arthura P. Whitakera), do około lat 80. XIX wieku, Ameryka Łacińska była otwarta zarówno na idee, jak i inwestycje zagraniczne, a równocześnie nie chroniła swej kultury i instytucji. Jego zdaniem, od lat 80. XIX w. nacjonalizm w regionie przybrał silniejszą postać (również pod względem ideologicznym), stając się równocześnie bardziej nacechowany kulturowo. Dotychczasowe wpływy oraz inwestycje amerykańskie i brytyjskie zaczęto postrzegać znacznie bardziej krytycznie niż dotychczas. W XX wieku natomiast na skutek polityki amerykańskiej i amerykańskich interwencji wojskowych nacjonalizm przybrał postać antyamerykanizmu.

Wiarda wskazał też kilka powodów powolnego rozwoju nacjonalizmu (modern nationalism) w regionie w XIX wieku. Po pierwsze, wymienił powody geopolityczne, takie jak wolny proces uzyskiwania niezależności i ustalania granic między państwami, w tym wyłanianie się mniejszych państw z początkowo większych tworów politycznych takich, jak Wielka Kolumbia, Republika Nowej Grenady oraz Zjednoczone Prowincje Ameryki Środkowej. Po drugie, zwrócit uwagę na niesprzyjające rozwojowi nacjonalizmu prądy takie jak silna myśl panlatynoamerykańska oraz silne lojalności lokalne względem „małej ojczyzny” (patria chica). Po trzecie, czynnikiem spowolniającym dynamikę rozwoju nacjonalizmu były też w dużym stopniu niezasymilowane niepiśmienne grupy indiańskie, które często okazywały lojalność wobec konkretnego przywódcy, a nie wobec „tak abstrakcyjnego i bezosobowego tworu jak państwo narodowe" (Wiarda, 2001, s. 178). Wreszcie, po czwarte,

\footnotetext{
4 Zob. analiza rozwoju dyskursu elit na temat rasy w regionie: Appelbaum, Macpherson, and Rosemblatt (2003).
} 
po zerwaniu zależności od Hiszpanii „brak było zewnętrznego wroga porównywalnego z najeźdźczymi armiami Napoleona, który stymulowałby nacjonalizm latynoamerykański na początku XIX wieku, jak było w wypadku Europy na ziemiach okupowanych przez oddziały Napoleona" (Wiarda, 2001, s. 178).

\section{WYBRANE CECHY PROCESÓW NARODOTWÓRCZYCH W AMERYCE ŁACIŃSKIEJ}

Do początków XX wieku społeczeństwa Ameryki Łacińskiej przeszły podobne fazy rozwoju: zerwanie z kolonializmem, wyzwolenie niewolników oraz rozwój oparty na eksporcie, przyciągający dużą liczbę imigrantów (Holt, 2003). Istotne znaczenie dla zrozumienia i analizy procesów narodotwórczych w Ameryce Łacińskiej mają w szczególności charakterystyka społeczności stanowiącej podstawę formującego się narodu oraz rola państwa i elit.

\section{Charakterystyka społeczności}

Brazylijski antropolog Darcy Ribeiro dobrze uchwycił różnice w przebiegu procesów rozwojowych oraz procesów narodotwórczych w regionie. Jego klasyfikacja ilustruje duże znaczenie cech społeczności stojących u podstaw poszczególnych narodów, w tym stopnia jej integracji, np. różnych grup kulturowych/etnicznych (imigranci, Indianie) oraz rasowych (czarnoskórzy, Azjaci). Zróżnicowanie etniczne, kulturowe i rasowe było początkowo postrzegane jako jedna z największych przeszkód w rozwoju wyłaniających się krajów (Larrain, 2000).

Za Ribeiro, w Ameryce Łacińskiej można wyróżnić trzy grupy narodów (ludów, pueblos) o podobnej charakterystyce: Pueblos Testimonio (Meksyk, Ameryka Środkowa, Peru, Boliwia, Ekwador), Pueblos Nuevos (Kolumbia, Wenezuela, Brazylia, Chile i kraje Karaibów) oraz Pueblos Transplantados (Argentyna i Urugwaj).

Na te pierwsze składają się współcześni reprezentanci starych autonomicznych cywilizacji, które zburzyła europejska ekspansja. Drugą grupę, określaną jako Pueblos Nuevos reprezentują narody amerykańskie uformowane w ostatnich wiekach jako produkt ekspansji europejskiej poprzez fuzję i akulturacje macierzy indiańskich, czarnych i europejskich. Trzecia grupa - Pueblos Transplantados - składa się z narodów powstałych poprzez implantację na terenach zamorskich europejskich kontyngentów, które utrzymały swój profil etniczny, swój język oraz oryginalną kulturę (Ribeiro, 1992, s. 69).

Koncepcja pueblos transplantados Ribeiry zbieżna jest z cechami modelu osadniczego socjologa Jerzego J. Wiatra (1969). Według tego modelu wyłonienie się narodu następuje przez „integrację osadników przybywających z innych kontynentów, przy eliminacji i wypchnięciu poza ramy tworzącego się narodu pierwotnych mieszkańców terytorium, na którym dokonuje się proces narodotwórczy" (s. 281)5. Jedną z ważnych cech modelu jest walka z ludnością rodzimą mająca na celu jej eksterminację bądź usunięcie poza granice państwowe. Działaniom tym towarzyszy poczucie wyższości (m.in. rasowej) oraz funkcjonujące w grupie mity i uprzedzenia. Taką właśnie droge obrały w II połowie XIX wieku Argentyna, Urugwaj oraz Chile, prowadząc politykę eksterminacji Indian, przy równoczesnym wspieraniu imigracji z Europy.

5 Zob. też Kula (1980). 
Zgodnie z osadniczym modelem powstawania narodu integracja następuje wokół określonego trzonu etnicznego, odgrywającego przywódczą rolę (Wiatr, 1969). Kulturową i etniczną podstawę narodów republikańskich podkreśla także Anthony D. Smith (2009) w kontekście USA:

(...) Czarnoskórych - i niewolników, i ludzi wolnych - postrzegano jako odrębną kategorię etniczną (w tym wypadku rasową), i trzeba było wielu wieków konfliktów i protestów, by uznano ich za pełnoprawnych Amerykanów. Poza tym nawet wśród białych szeroko uznawano anglosaską podstawę etniczną i dominację wyłaniającego się narodu amerykańskiego. Przykłady te ujawniają wage elementu etnicznego w nacjonalizmie republikańskim, a przez to kwestionują modne podejście polaryzujące nacjonalizmy "obywatelskie" i "etniczne" (choć nie kwestionują samego rozróżnienia między nimi) (s. 186).

O ile zatem Stany Zjednoczone kształtowały się wokół trzonu anglosaskiego, o tyle w wypadku Hispanoameryki była nim hiszpańskojęzyczna grupa kreolska oraz Hiszpanie.

\section{Państwo}

Wśród teoretyków narodu i nacjonalizmu, moderniści przypisują państwu oraz elicie politycznej i intelektualistom szczególną rolę w procesach narodotwórczych. Uformowanie państwa jest też punktem wyjścia w postkolonialnym modelu genezy narodu opisanym przez Wiatra ${ }^{6}$. Szczególna rola państwa wynika z tego, że za pomocą swoich instytucji (edukacyjnych, kulturowych itd.) artykułuje ono i rozpowszechnia określony dyskurs tożsamości narodowej.

Z tej perspektywy szczególna rola państwa w Ameryce Łacińskiej wydaje się kluczowa, biorąc pod uwagę, z jednej strony, że granice niepodległych państw ustalono, nie respektując "naturalnych" granic lokalnych grup indiańskich, w rezultacie czego ta sama społeczność może mieszkać obecnie na obszarze dwóch i więcej państw (np. Indianie Keczua), a z drugiej strony z tego, że wiele krajów regionu przyjęło tysiące (lub miliony) imigrantów z Europy i Azji. Argumentem przeciwko ważnej funkcji państwa jest spostrzeżenie Anthony'ego Smitha, że ustanowienie instytucji państwowych nie jest gwarancją, że populacja będzie się rzeczywiście identyfikować kulturowo z danym państwem lub będzie akceptować "mit narodowy" (Miller, 1999). W odniesieniu do Ameryki Łacińskiej jest to szczególnie trafna uwaga, ponieważ, jak zauważa Miller, „przez większość XX wieku państwo nadal sprawowało [tam] jedynie niewielką władzę nad dużymi obszarami terytoriów narodowych" (Miller, 1999, s. 37).

Do niedawna szeroko uznawano stanowisko, zgodnie z którym powstanie państw poprzedzało powstanie narodów w Ameryce Łacińskiej. Zakładano też, jak wskazuje Miller, że do lat 50. XX wieku nie zaczęła się jeszcze nawet kształtować szeroka świadomość narodowa. Jednak nowsze prace ukazują tworzenie państwa i rozwój narodu jako „procesy powiązane, zachodzące równolegle, czasem się nawzajem wzmacniające, a czasem ostabiające" (Miller, 2006, s. 212)7.

6 Niektóre narody latynoamerykańskie wykazują pewne cechy opisanego przez Wiatra (1969) modelu postkolonialnego. Latynoamerykaniści z ostrożnością podchodzą jednak do stosowania koncepcji postkolonializmu wobec Ameryki Łacińskiej.

7 Miller (2006) wskazuje np. prace T. Halperína Donghi, Proyecto y construcción de una nación (Argentina, 1846-1880) z 1980 r. jako przykład równoczesnej analizy obu procesów. 
Zgodnie z optyką modernistów elity polityczne oraz intelektualiści pełnią ważną rolę w kształtowaniu tożsamości narodowej ${ }^{8}$. Wkładają oni wiele wysitku w integrację różnych grup $w$ ramach szerokiego projektu narodowego. Ów projekt (dyskurs tożsamości) jest tworem pewnej elity przywódczej, która następnie w sposób świadomy, celowy i zaplanowany, "W oparciu o państwo" i jego instytucje stara się upowszechnić poczucie narodowe wśród pozostałych grup społeczeństwa, o czym w odniesieniu do państw postkolonialnych pisał Wiatr (1969). Projekt ten powstaje w oparciu o wyznawane przez elity ideologie i dominującą myśl społeczno-polityczną. Przykładowo, na przełomie XIX i XX wieku w regionie silny wpływ miała myśl pozytywistyczna i jej postulaty postępu (jak w wypadku Domingo F. Sarmiento i Juana Bautisty Alberdiego w Argentynie) (Wiarda, 2001).

Liderzy i elity polityczne. Ustanowione symbole narodowe (flaga, godło, hymn) oraz święta i ceremonie publiczne ${ }^{9}$ mogą się stać elementami „politycznej religii ludu" (Smith, 2009, s. 61) - swoistej religii obywatelskiej umacniającej naród. Szerzeniu poczucia przynależności i identyfikacji służyły też kult bohaterów (np. Simóna Bolivára) i mity narodowe, jak również monumenty (pomniki, nazwy ulic) oraz „papierowe monumenty” (czyli jednostki monetarne i przedstawienia na znaczkach pocztowych) (Centeno, 1999, ss. 75-106). Wszystkie one powstawały z inicjatywy rządzących, legitymizując ich władzę (Centeno, 1999). Obrazy na znaczkach w Ameryce hiszpańskiej szczególnie od lat 70. XIX wieku miały nacjonalistyczny wydźwięk i ukazywały bohaterów walk, miejscową faunę i florę, pejzaże, symbole republikańskie, później także postacie indiańskie oraz czarnoskóre (Achugar, 2009). Owe „publiczne sale lekcyjne” (public classrooms), jak zauważa Centeno, "używają historii do rozpowszechniania polityki przez tworzenie iluzji jedności i solidarności" (1999, s. 79). W Argentynie po 1887 roku wzniesiono szereg pomników bohaterów narodowych i „świątyń" kultu ojczyzny, m.in. Múseo Histórico Nacional (dekret z 1889 r.) (Bertoni, 1992). Z kolei w Urugwaju powstały m.in. pomniki imigranta "El Inmigrante" (1921), pomnik gaucho (1927) oraz czarnoskórego dostawcy wody "El aguatero" (1932), na którego postumencie umiszczono hołd dla rasy czarnej. Swoistym „pomnikiem" był tam stadion Stulecia (Centenario) zbudowany przed mistrzostwami świata w piłce nożnej w 1930 roku (Islas, 2008). Na "masowe i ujednolicone wychowanie publiczne" zwrócit też uwage Smith w rozważaniach na temat ideologii narodu republikańskiego, który uznaje za dominującą formę narodu w Ameryce Łacińskiej (Smith, 2009, s. 180). Ważnym elementem ekspresji tożsamości narodowej są dla wielu autorów również sztuka wizualna (np. malarstwo, wizerunki, ikonografia) (Achugar, 2009).

Elity polityczne i ideolodzy mieli wpływ na upowszechnianie świadomości narodowej i wspólnej kultury narodowej nie tylko za pomocą, jak określa to Znaniecki, „propagandy" (np. kult bohaterów), ale także kształcenia (Znaniecki, 1990, ss. 123-124). Poprzez włączenie do zuniformizowanych programów szkolnictwa powszechnego przedmiotów takich jak historia czy geografia (oraz przygotowanie odpowiednich podręczników), uczniowie zdobywali wiedzę o państwie i narodzie. Kształcenie w języku narodowym oraz nauczanie literatury były nie tylko sposobem tworzenia jedności, ale też wpajania dumy narodowej. Z tego właśnie powodu kształcenie imigrantów w Argentynie, Urugwaju czy

\footnotetext{
8 Na temat formowania kultury narodowej i roli ideologów, intelektualistów (np. pisarzy, historyków, etnografów) i artystów itd. zob. też Znaniecki (1990).

9 Na temat kodów służących konstruowaniu tożsamości zbiorowej (np. kod ogłady lub cywilizowania, kod świętości, kod pierwotności, zob. Bokszański (2005).
} 
Brazylii oraz organizowanie świąt obywatelskich (fiestas patrias) w duchu patriotycznym były najlepszym sposobem włączania ich do wspólnoty i kultury narodowej, szczególnie w wypadku tych grup imigranckich, które wyrażały ciągłe przywiązanie do kraju pochodzenia, jak Włosi w Argentynie (Bertoni, 1992; Caetano, 2000; Schulze, 2014) ${ }^{10}$. Z kolei za pomocą polityki migracyjnej władze miały bezpośredni wpływ na kształtowanie zbiorowości w obrębie państwa, przyjmując pewne grupy, a zakazując wstępu innym (KaganiecKamieńska, 2012).

Mimo ich bezsprzecznego wkładu, Miller (1999) zwraca uwagę, że rola elit politycznych w kształtowaniu narodu i tożsamości narodowej nie jest jednak wystarczająca, nie wyjaśnia bowiem dlaczego zwykli ludzie zaczynają postrzegać nacjonalizm jako ważny dla nich. Ponadto, „[n]awet jeśli wszystkie narody są skonstruowane, to niektóre posiadają silniejsze podstawy $w$ istniejących praktykach kulturowych i wspólnej historii niż inne (...)" (Miller, 2006, s. 211). Przykładowo, próby konsolidacji tożsamości narodowej w porewolucyjnym Meksyku opierały się zarówno na czynniku obywatelskim (czerpiącym m.in. z mitologii rewolucji meksykańskiej), jak i etnicznym w postaci dziedzictwa indiańskiego oraz ideologii metysażu (Miller, 1999). Państwo odegrało tutaj rolę kluczową, kontrolując i sponsorując realizacje pewnych wizji proponowanych przez intelektualistów, jak choćby projektu murali w Mieście Meksyk (Craven, 2006).

Intelektualiści. Przykładem intelektualisty, który wywarł duży wpływ na przełomie XIX i XX wieku jest Bartolomé Mitre (1821-1906) - historyk, intelektualista, polityk, późniejszy prezydent Argentyny, uważany za twórcę mitu założycielskiego Argentyny i jednego z kluczowych "konstruktorów” narodu argentyńskiego. Mitre uważał, że projekt tworzenia jedności narodowej wymaga wsparcia się na przeszłości (Devoto, 2002). W 1857 roku wraz z Domingo F. Sarmiento stworzył "kolekcję biografii, które stanowią podstawe oficjalnej historii: Galería de celebridades argentinas" (2010, s. 256). Znaleźli się w niej m.in. libertador José de San Martín, Bernardino Rivadavia oraz twórca flagi - Manuel Belgrano. Jego prace z okresu, kiedy Argentyna podzielona była jeszcze na dwa państwa (estados) - Buenos Aires i Konfederację Argentyńską - zdawały się usprawiedliwiać zasadność zjednoczenia, powołując się na wspólną przeszłość. Wizja Mitre i jego prace nie od razu jednak się spopularyzowały, między innymi dlatego, że ówczesne elity początkowo koncentrowały się na przyszłości, a w edukacji podkreślano raczej podejście naukowe i techniczne niż humanistyczne i patriotyczne. Dopiero później, kiedy zdano sobie sprawę z konieczności stworzenia narodu z różnorodnej tkanki etnicznej i narodowej (ludności lokalnej i imigrantów), odwoływanie się do przeszłości stało się najlepszym instrumentem umożliwiającym zbudowanie przyszłości narodu. Mitre był też pomysłodawcą i twórcą wielu instytucji, jak choćby Instituto Histórico y Geográfico del Río de la Plata (1854) (Devoto, 2002).

Jak zauważa Miller, rola intelektualistów w poszczególnych krajach i w różnych okresach zależała od ich relacji z państwem i nie wszędzie miała równie ważne znaczenie. Niektórzy myśliciele - szczególnie w II połowie XIX wieku - zyskali status „ojców założycieli” (w tym Domingo Faustino Sarmiento w Argentynie oraz José Martí na Kubie. Niemniej jednak, „wpływ XX-wiecznych intelektualistów latynoamerykańskich ograniczony był ich problematycznym związkiem z państwem (...): tam, gdzie państwo wspierało i sponsorowało ich pracę, jak w Meksyku lub Brazylii, cieszyli się oni znaczącym wpływem; nato-

10 Na temat kształtowania systemu edukacji w Argentynie zob. np. Martínez Paz (2001). Na temat rytuatów obywatelskich zob. np. Irazuzta (2001). 
miast tam, gdzie państwo pracę tę ignorowało i represjonowało, jak w Argentynie, mieli oni znacznie mniejszy wpływ" (Miller, 2006, s. 213).

Jednym słowem, idee intelektualistów były włączane do projektów narodotwórczych na zasadach ustalonych przez państwo (Miller, 1999).

\section{NARÓD PRZEDEFINIOWANY}

Procesy zachodzące w Ameryce Łacińskiej do około połowy XX wieku były wynikiem dynamicznych i burzliwych zmian demograficznych, społecznych i kulturowych. Późniejsza walka o prawa kulturowe ludności indiańskiej (Posern-Zieliński, 2005) i grupy o korzeniach afrykańskich oraz wprowadzanie stosownych zmian legislacyjnych ${ }^{11}$ były i nadal są wyzwaniem dla tożsamości narodowych w regionie. Powoduje to konieczność przyjęcia nowej perspektywy oraz ewentualnego przedefiniowania koncepcji narodu i tożsamości narodowej w ramach wielokulturowości.

Innym nowym wyzwaniem dla perspektywy narodowej są ruchy migracyjne. Wielu badaczy przyjęło zatem inną optykę w postrzeganiu i analizowaniu dotychczasowego ujęcia tożsamości, zwracając się ku pojęciu „transnarodowości”. Wskazuje ono na rozwój więzi społecznych, kulturowych, gospodarczych i politycznych ponad granicami narodowymi, również w wypadku migrujących społeczności indiańskich (Vertovec, 2009; Duany 2011; Velasco Ortiz, 2005).

\section{BIBLIOGRAFIA}

Achugar, H. (2009). Foundational images of the nation in Latin America. W W. G. Acree Jr. \& J. C. González Espitia (Red.), Building nineteenth-century Latin America: Re-rooted cultures, identities and nations (ss. 11-31). Nashville: Vanderbilt University Press.

Anderson, B. (1997). Wspólnoty wyobrażone: Rozważania o źródłach i rozprzestrzenianiu się nacjonalizmu. Kraków: Społeczny Instytut Wydawniczy Znak-Fundacja im. Stefana Batorego.

Appelbaum, N. P., Macpherson, A. S., \& Rosemblatt, K. A. (2003). Introduction: Racial nations. W N. P. Appelbaum, A. S. Macpherson, \& K. A. Rosemblatt (Red.), Race and nation in modern Latin America (ss. 1-31). Chapel Hill: The University of North Carolina Press.

Base de Datos Políticos de las Américas. (2006, kwiecień). Derechos de los Pueblos Indígenas. Pobrano 11 lutego 2016, z http://pdba.georgetown.edu/Comp/Derechos/indigenas.html

Bertoni, L. A. (1992). Construir la nacionalidad: heroes, estatuas y fiestas patrias, 18871891. Boletín del Instituto de historia Argentina y Americana "Dr. E. Ravignani”, (5/1 semestre), 77-111.

Bokszański, Z. (2005). Tożsamości zbiorowe. Warszawa: PWN.

11 M.in. w konstytucjach wielu państw potwierdzających ich wieloetniczną i wielokulturową naturę, np. Meksyk (1992), Peru (1993), Boliwia (1994), Ekwador (1996) („Base de Datos Políticos de la Américas”, 2006). 
Caetano, G. (Coord.). (2000). Los Uruguayos del Centenario: Nación, ciudadanía, religión y educación (1910-1930). Montevideo: Taurus-Ediciones Santillana.

Centeno, M. A. (1999). War and memories: Symbols of state nationalism in Latin America. European Review of Latin American and Caribbean Studies, (66), 75-106.

Chiaramonte, J. C. (1989). Formas de identidad en el Río de la Plata luego de 1810. Boletín del Instituto de historia Argentina y Americana "Dr. E. Ravignani", (1/1 ${ }^{\text {er }}$ semestre), 71-92.

Chiaramonte, J. C. (1997a). Ciudades, provincias, Estados: Orígenes de la Nación Argentina (1800-1846). Buenos Aires: Ariel.

Chiaramonte, J. C. (1997b). La formación de los Estados nacionales en Iberoamérica. Boletín del Instituto de historia Argentina y Americana „Dr. E. Ravignani”, (15/1 ${ }^{\mathrm{er}}$ semestre), 143-165.

Craven, D. (2006). Art and revolution in Latin America 1910-1990. New Haven: Yale University Press.

Devoto, F. J. (2002). Nacionalismo, fascismo y tradicionalismo en la Argentina moderna. Una historia. Buenos Aires: Siglo XXI de Argentina Editores.

Duany, J. (2011). Blurred borders: Transnational migration between the Hispanic Caribbean and the United States. Chapel Hill: The University of North Carolina Press. http://dx.doi.org/10.5149/9780807869376_duany

Galasso, N. (2010). El pensamiento national. W R. Hamawi \& R. O. Tizzani (Red.), Argentina 1810-2010: Bicentenario (ss. 255-272). Buenos Aires: Secretaría de Cultura de la Presidencia de la Nación.

Granados García, A. (2009). Congresos e intelectuales en los inicios de un proyecto y de una conciencia continental latinoamericana, 1826-1860. W A. Granados García \& C. Marichal (Comp.), Construcción de las identidades latinoamericanas: Ensayos de historia intelectulas (siglos XIX y XX) (ss. 39-69). México: El Colegio de México.

Halperín Donghi, T. (1980). Proyecto y construcción de una nación (Argentina 1848-1880). Caracas: Biblioteca Ayacucho.

Holt, T. C. (2003). Foreword. W N. P. Appelbaum, A. S. Macpherson, \& K. A. Rosemblatt (Red.), Race and nation in modern Latin America (ss. vii-xiv). Chapel Hill: The University of North Carolina Press.

Irazuzta, I. (2001). Argentina: Una construcción ritual: Nación, identidad y clasificación simbólica en las sociedades contemporáneas. Bilbao: Universidad del País Vasco.

Islas, A., \& Frega, A. (2008). Identidades uruguayas: Del mito de la sociedad homogénea al reconocimiento de la pluralidad. W Historia del Uruguay en el siglo XX (1890-2005) (ss. 359-392). Montevideo: Ediciones de la Banda Oriental.

Kaganiec-Kamieńska, A. (2012). Polityka imigracyjna wybranych państw Ameryki Łacińskiej na przetomie XIX i XX w. Studia Migracyjne-Przegląd Polonijny, (4), 57-82.

Kula, M. (1980). Kilka uwag o asymilacji w świetle doświadczeń latynoamerykańskich. W H. Kubiak \& A. Paluch (Red.), Założenia teorii asymilacji (ss. 39-51). Kraków: Zakład Narodowy im. Ossolińskich, PAN.

Larrain, J. (2000). Identity and modernity in Latin America. Malden MA: Polity Press-Blackwell Publishers Ltd.

Lomnitz, C. (2001). Nationalism as a practical system: Benedict Anderson's theory of nationalism from the vantage point of Spanish America. W M. A. Centeno \& F. LopezAlves (Red.), The other mirror: Grand theory through the lens of Latin America (ss. 329-359). Princeton: Princeton University Press. 
Martínez Paz, F. (2001). La enseñanza primaria, secundaria y universitaria (1862-1914). W Nueva Historia de la nación Argentina (T. 6, ss. 277-307). Buenos Aires: Planeta.

Miller, N. (1999). In the shadow of the state: Intellectuals and the quest for national identity in twentieth-century Spanish America. New York: Verso.

Miller, N. (2006). The historiography of nationalism and national identity in Latin America. Nations and Nationalism, 12(2), 201-221. http://dx.doi.org/10.1111/j.14698129.2006.00237.x

Myers, J. (2006). Language, history and politics in Argentine identity, 1840-1880. W D. H. Doyle \& M. A., Pamplona (Red.), Nationalism in the new world (ss. 117-142). Athens, Georgia: The University of Georgia Press.

Posern-Zieliński, A. (2005). Między indygenizmem a indianizmem. Poznań: Wydawnictwo Naukowe UAM.

Puigbó, R. (1998). La identidad nacional argentina y la identidad iberoamericana. Buenos Aires: Grupo Editor Latinoamericano.

Ribeiro, D. (1992). Las Americas y la civilización: Proceso de formación y causas del desarrollo desigual de los pueblos americanos. Caracas: Biblioteca Ayacucho.

Schulze, F. (2014). Nation and migration: German-speaking and Japanese immigrants in Brazil, 1850-1945. W M. Goebel \& N. Foote (Red.), Immigration and national identities in Latin America (ss. 115-138). Gainesville: University Press of Florida. http://dx.doi. org/10.5744/florida/9780813060002.003.0005

Smith, A. D. (2009). Kulturowe podstawy narodów: Hierarchia, przymierze i republika. Kraków: Wydawnictwo Uniwersytetu Jagiellońskiego.

Velasco Ortiz, M. L. (2005). Mixtec transnational identity. Tucson: The University of Arizona Press.

Vertovec, S. (2009). Transnarodowość. Kraków: Wydawnictwo Uniwersytetu Jagiellońskiego.

Wade, P. (1997). Race and ethnicity in Latin America. New York: Pluto Press.

Wade, P. (2009). Race and sex in Latin America. New York: Pluto Press.

Wiarda, H. J. (2001). The soul of Latin America: The cultural and political tradition. New Haven: Yale University Press.

Wiatr, J. J. (1969). Naród i państwo: Socjologiczne problemy kwestii narodowej. Warszawa: Książka i Wiedza.

Wojcieszak, J. (1989). Dylemat uniwersalizmu i partykularyzmu w hispanoamerykańskiej filozofii kultury lat 1900-1960. Warszawa: CESLA.

Znaniecki, F. (1990). Wspótczesne narody. Warszawa: PWN. 